\title{
PENGUNAAN ENDAPAN AIR GAMBUT SEBAGAI AMELIORAN ALTERNATIF TERHADAP BEBERAPA SIFAT KIMIA ULTISOL DAN HASIL TANAMAN JAGUNG SEMI (Zea mays L)
}

\author{
Teguh Budi Prasetyo, Husnita, Irwan Darfis \\ Jurusan Tanah Fakultas Pertanian Universitas Andalas
}

\begin{abstract}
The main problems of Ultisols are high $\mathrm{Al}$ concentration, low $\mathrm{pH}$, low cation exchangeable capacity (CEC), and low fertility. The objectives of this reasearch were to study the effect of peat water deposit to some chemical properties of Ultisols and to determine the optimal level of peat water deposit for optimum corn yield. The experimental design was the complete randomized design that consisted of 5 levels of peat water deposit $(0,800,1600,2400$, and $3200 \mathrm{~kg} / \mathrm{ha}$ ). The results showed that the application of peat water deposit could reduce exchangeable $\mathrm{Al}$, increase $\mathrm{CEC}$ and soil $\mathrm{P}$ concentration, P-uptake, and corn yield. The highest corn yield was obtained at application of $3200 \mathrm{~kg}$ peat water deposit /ha.
\end{abstract}

Key Words : Ultisols, peat water precipitation, soil chemical characteristics, corn

\section{PENDAHULUAN}

Peranan sektor pertanian sangatlah penting dalam pembangunan nasional, terutama dalam pengembangan swasembada pangan. Akan tetapi dinamika pembangunan yang berjalan pesat mengakibatkan lahan pertanian berkurang sedangkan penggunaan lahan yang tidak sesuai dengan kaedahkaedah konservasi dapat menurunkan tingkat kesuburan tanah. Oleh sebab itu upaya ekstensifikasi pertanian terpaksa diarahkan pada tanah-tanah marginal, diantaranya adalah tanah-tanah yang bereaksi masam. Salah satu tanah yang beraksi masam di Indonesia yang penyebarannya luas adalah ultisol, kira-kira $35 \%$ dari luas daratan Indonesia (Hakim, Nyakpa, Lubis, Nugroho, Saul, Hong, Bailey, 1986).

Penggunaan ultisol sebagai lahan pertanian mempunyai banyak kendala baik sifat fisika dan kimia sehingga produksi tanaman menjadi rendah (Soepardi, 1983). Sifat kimia yang kurang baik dari ultisol dicirikan oleh kemasaman yang tinggi dengan $\mathrm{pH}$ kurang dari 5,5, kandungan bahan organik (BO) rendah sampai sedang, kejenuhan basa (KB) kurang dari 35\%, kandungan hara Nitrogen $(\mathrm{N})$, Fosfor $(\mathrm{P})$, Kalium (K) dan Kalsium (Ca) rendah,
Kapasitas Tukar Kation (KTK) kecil dari 24 me/100 g tanah serta kelarutan Alumunium $(\mathrm{Al})$, Besi $(\mathrm{Fe})$ dan Mangan (Mn) tinggi (Sarief, 1986).

Upaya-upaya yang telah dilakukan untuk mengatasi masalah-masalah di atas antara lain pengapuran dan pemberian bahan organik baik dalam bentuk kompos, pupuk kandang maupun pupuk hijau yang diiringi pemberian pupuk buatan yang telah sering dilakukan. Penggunaan kapur sudah dilakukan untuk memperbaiki kesuburan ultisol dan memberikan hasil yang cukup memuaskan. Pemberian kapur 2-6 ton/ha pada tanah podzolik mampu meningkatkan produksi tanaman padi, palawija dan kacangan yang beragam dari $50 \%$ sampai 400 \% (Nyakpa, Lubis, Pulung, Munawar, Hong dan Hakim, 1988).

Pemberian bahan amelioran baik dalam bentuk kompos, pupuk kandang maupun pupuk hijau dapat memperbaiki kesuburan tanah Ultisol, tetapi itu semua mempunyai kelemahan baik dalam penyediaan bahan mentah kompos dan pupuk

kandang, pengomposan yang membutuhkan waktu cukup lama, dalam penambahan pupuk hijau yang memerlukan lahan dan biaya yang relatif tinggi dalam aplikasi di 
lapangan karena perlu biaya transportasi dan pemberiannya ke lapangan.

Sebagai alternatif pengganti bahan amelioran diusulkan untuk menggunakan endapan dari air gambut. Air gambut adalah air permukaan atau air tanah yang banyak terdapat di daerah rawa (Taufik, 1985). Air ini mengandung senyawa organik terlarut yang berasal dari tanah gambut (Kusnaedi, 1995). Syam (2006) melaporkan bahwa pemberian asam humat 50,100, 150 dan 200 ppm yang beasal dari ekstrak tanah gambut mampu meningkatkan $\mathrm{pH}, \mathrm{P}$ tersedia, KTK serta menurunkan Al-dd dan Fe-dd tanah ultisol.

Dengan pertimbangan bahwa air gambut banyak terdapat pada saluran drainase pada lahan gambut yang sampai saat ini dibiarkan percuma. Adapun menggunakan teknologi yang sederhana yaitu menambahkan tepung biji kelor dengan perbandingan $1 \mathrm{~g}: 1000 \mathrm{ml}$ air gambut maka senyawa organik yang terkandung dalam air gambut akan diendapkan, dimana biji kelor mengandung senyawa protein yang dapat menggumpalkan partikel-partikel koloid penyebab kekeruhan pada air gambut (Rahma, 1998). Teknologi yang sederhana ini dinilai sangat murah bila dibandingkan dengan metoda ekstraksi bahan humat yang memerlukan bahan humat yang banyak dan mahal serta prosedur yang rumit dan belum adanya penelitian tentang bahan endapan dari air gambut sebagai amelioran alternatif.

Tanaman indikator yang digunakan dalam penelitian ini adalah tanaman jagung semi. Tanaman jagung semi merupakan salah satu komoditas pertanian yang disukai oleh masyarakat, karena rasanya enak, mengandung karbohidrat, protein dan vitamin yang tinggi serta kandungan lemak yang rendah. Bagi petani

komoditas ini merupakan harapan, karena daya jualnya yang cukup tinggi dari pada jagung biasa (Iskandar, 2003).

Tujuan penelitian ini adalah : (1) untuk mempelajari pengaruh pemberian endapan dari air gambut terhadap beberapa sifat kimia tanah ultisol yaitu Al-dd, $\mathrm{pH}$, KTK dan P, (2) untuk menentukan takaran endapan dari air gambut yang optimal dalam mendukung hasil tanaman jagung semi.

\section{BAHAN DAN METODA}

Tanah yang digunakan adalah Ultisol yang diambil dari Kebun Percobaan Fakultas Pertanian Universitas Andalas. Sebagai perlakukan menggunakan endapan air gambut. Pupuk dasar yang digunakan adalah Urea, $\mathrm{KCl}$, SP-36 dan dolomit sebagai sumber $\mathrm{Ca}$ dan $\mathrm{Mg}$. Tanaman indikator digunakan adalah jagung hibrida varietas Andalas (A4) yang dipanen selagi muda (jagung semi) untuk lebih jelas deskripsi tanaman jagung ditampilkan pada Lampiran 2. Selanjutnya bahan dan alat yang digunakan selengkapnya dapat dilihat pada Lampiran 3 dan 4.

Rancangan percobaan yang digunakan adalah Rancangan Acak Lengkap (RAL). Perlakuan yang diberikan adalah endapan air gambut sebanyak 5 perlakuan dengan 3 ulangan. Selanjutnya untuk melihat perbedaan antar perlakuan digunakan uji $\mathrm{F}$ pada taraf $5 \%$ dan jika berbeda nyata dilanjutkan dengan uji Duncan's New Multiple Range Test (DNMRT) pada taraf $5 \%$. Denah penempatan unit perlakuan ditampilkan pada Lampiran 5.

Dimana perlakuannya sebagai berikut :

$\mathrm{G} 0=0 \mathrm{~g}$ Endapan dari air gambut $/ 10 \mathrm{~kg}$ tanah ( $0 \mathrm{~kg}$ endapan dari air gambut/ Ha)

$\mathrm{G} 1=4 \mathrm{~g}$ Endapan dari air gambut $/ 10 \mathrm{~kg}$ tanah $(800 \mathrm{~kg}$ endapan dari air gambut/ Ha)

$\mathrm{G} 2=8 \mathrm{~g}$ Endapan dari air gambut $/ 10 \mathrm{~kg}$ tanah $(1600 \mathrm{~kg}$ endapan dari air gambut/ Ha)

$\mathrm{G} 3=12 \mathrm{~g}$ Endapan dari air gambut $/ 10 \mathrm{~kg}$ tanah $(2400 \mathrm{~kg}$ endapan dari air gambut/Ha)

$\mathrm{G} 5=16 \mathrm{~g}$ Endapan dari air gambut $/ 10 \mathrm{~kg}$ tanah $(3200 \mathrm{~kg}$ endapan dari air gambut/ Ha) 
Penentuan takaran endapan dari air gambut ini didasarkan pada dosis pemberian bahan organik yaitu 20 ton/ha (Hakim et al, 1986). Dengan asumsi kadar asam humat 2 $\%$ sehingga diperoleh asam humat sebanyak $400 \mathrm{~kg} / \mathrm{ha}$. Tanah yang digunakan $10 \mathrm{~kg}$ setara berat kering mutlak.

Bahan endapan dari air gambut diperoleh dengan menambahkan $1 \mathrm{~g}$ tepung biji kelor kedalam $1000 \mathrm{~mL}$ air gambut. Penambahan tepung biji kelor dilakukan secara perlahan-lahan sambil diaduk dan dibiarkan selama 1 jam. Tepung biji kelor ini berfungsi untuk mengendapkan senyawa organik yang terlarut pada air gambut. Kemudian dilakukan penyaringan sehingga didapatkan bahan endapan dari air gambut. Kemudian dilakukan penimbangan terhadap bahan endapan dari air gambut untuk melihat berapa perbandingan antara tepung biji kelor dan bahan yang diendapkan. Untuk $1 \mathrm{~g}$ tepung biji kelor dalam $1000 \mathrm{~mL}$ air gambut didapatkan bahan endapan dari air gambut $4 \mathrm{~g}$.

Pengambilan contoh tanah dilakukan secara komposit pada kedalaman $0-20 \mathrm{~cm}$ dari permukaan tanah kemudian dikering anginkan. Setelah itu tanah diaduk secara homogen dan ditimbang $10 \mathrm{~kg}$ setara berat kering mutlak untuk mengisi polybag. Kemudian sisa tanah diambil $200 \mathrm{~g}$ dan dihaluskan dengan ayakan $2 \mathrm{~mm}$ untuk analisis tanah awal.

Sebelum tanah dimasukkan ke dalam polybag, tanah diberi endapan sesuai perlakukan yaitu dengan mengaduknya dengan endapan dari air gambut (sesuai dengan perlakuan pada tiap-tiap polybagnya). Kemudian tanah dimasukkan kedalam polybag keadaan kapasitas lapang dan diinkubasi salama 2 minggu.

Pemupukan dan penanaman dilakukan setelah tanah siap diinkubasi. Kemudian ditanam benih jagung sebanyak 3 biji/polybag sedalam $5 \mathrm{~cm}$ dari permukaan tanah, seminggu kemudian dilakukan seleksi dan ditinggalkan satu tanaman yang terbaik untuk tiap polybag. Pemberian dolomit sebagai pupuk diberikan 1 minggu sebelum tanam (setelah inkubasi limbah pengolahan air gambut yaitu 2 minggu) sebanyak $500 \mathrm{~kg} / \mathrm{ha}(10 \mathrm{~g} /$ polybag$)$ dan pupuk buatan diberikan seluruhnya pada saat tanam disekeliling tanaman, kecuali pemberian urea, setengahnya pada saat tanam dan setengahnya lagi saat tanaman berumur 20 hari. Dosis pemupukan untuk tanaman jagung menurut Soeprapto (1991) jumlah pupuk $\mathrm{N}$ yang diperlukan oleh tanaman jagung sekitar $300 \mathrm{~kg}$ Urea/ha (6 g Urea/polybag), pupuk P sekitar $200 \mathrm{~kg} / \mathrm{ha}$ SP-36 (2 g SP-36/polybag) dan pupuk K sebesar $50 \mathrm{~kg} \mathrm{KCl} / \mathrm{ha}(1 \mathrm{~g} \mathrm{KCl} /$ polybag$)$.

Pemeliharaan tanaman meliputi penyiraman, penyiangan serta pencegahan hama dan penyakit. Penyiraman dilakukan tiap hari sampai panen dan diikuti dengan penyiangan. Untuk pencegahan hama dan penyakit dilakukan sejak tanaman berumur 3 minggu sampai menjelang panen. Penyemprotan dilakukan setiap satu minggu sekali dengan menggunakan Sevin $85 \mathrm{~S}$ dengan kosentrasi $2 \mathrm{cc} /$ liter dan fungisida Dithane M-45 kosentrasi 2 g/liter. Panen dilakukan pada umur 50 hari atau apabila rambut tongkol sudah mencapai $2-3 \mathrm{~cm}$, berwarna putih kemerah-merahan dan kelobot berwarna hijau.

Analisis tanah awal akan meliputi $\mathrm{pH}$ tanah dengan metoda elektrometrik, Ntotal dengan metoda Kjeldahl, $\mathrm{P}$ tersedia metoda Bray II, C-organik dengan metoda Walkey and Black, Ca-dd, Mg-dd, K-dd, Na-dd, dengan metoda pencucian ammonium asetat $1 \mathrm{~N}$ pH 7 dan diukur dengan AAS, KTK dengan metoda pencucian ammonium asetat $\mathrm{pH}$ 7, Al-dd dengan metoda Volumetri. Untuk analisis tanah setelah inkubasi (inkubasi 2 minggu) dilakukan terhadap $\mathrm{pH}, \quad$ Al-dd, KTK, dan P. Pada inkubasi 3 minggu analisis dilakukan untuk $\mathrm{pH}$ dan Al-dd ini bertujuan untuk melihat pengaruh kapur terhadap pH dan Al. Pengambilan sampel tanah dilakukan dengan cara mengaduk tanah secara merata untuk masing - masing perlakuannya. Analisis endapan dari air gambut meliputi $\mathrm{pH}$, C-organik, KTK, \% asam fulfat dan \% asam humat. 
Pengamatan tanaman meliputi tinggi tanaman, berat basah tanaman (batang, daun dan tongkol jagung) dan berat tongkol, dan kadar hara $\mathrm{P}$ tanaman. Untuk melihat pertumbuhan jagung dilakukan pemotretan.

\section{HASIL DAN PEMBAHASAN}

\section{Analisis Endapan dari Air Gambut}

Hasil analisis beberapa sifat kimia Endapan dari Air Gambut yaitu meliputi $\mathrm{pH}$, C-organik, KTK dan \% Asam Humat dapat dilihat pada Tabel 1.

Pada Tabel 1 dapat dilihat bahwa Endapan dari Air Gambut mempunyai $\mathrm{pH}$ yang rendah yaitu 3,43 . Hal ini disebabkan endapan air gambut yang mengandung bahan humat (seperti asam humat dan asam fulfat) yang mempunyai gugus fungsional yaitu karboksilat $(-\mathrm{COOH})$ dan $\mathrm{OH}$ fenolat yang merupakan sumber kemasaman yaitu berupa $\mathrm{H}^{+}$bila terjadi proses disosiasi $\mathrm{H}$ dari asam-asam tersebut.

Nilai KTK Endapan dari Air Gambut yaitu 97,60 me/100g ini menunjukkan bahwa muatan negatif yang dimiliki oleh Endapan dari Air Gambut relatif lebih banyak. Hal ini karena endapan dari air gambut mengandung bahan humat ( asam humat dan asam fulfat) yang mempunyai gugus fungsional karboksilat $(-\mathrm{COOH})$ dan $\mathrm{OH}$ fenolat, jika gugus fungsional tersebut terdisosiasi maka akan menyumbangkan sejumlah muatan negatif. Stevenson (1994 cit Herviyanti, 2007) menyatakan bahwa nilai KTK asam humat disebabkan karena asam humat mempunyai sumber muatan negatif yang berasal dari gugus fungsional hidroksil - $(\mathrm{OH})$ dan karboksil (-COOH). Semakin besar kosentrasi gugus fi onal asam humat maka semakin besar pula muatan negatif yang dikandungnya. Dengan adanya peristiwa ionisasi maka akan terbentuk tapak - tapak pertukaran sehingga kation lebih banyak terjerap.

\section{Analisis Tanah Setelah Inkubasi}

\section{Inkubasi dengan Endapan dari Air Gambut}

Hasil analisis beberapa sifat kimia Ultisol setelah diinkubasi dengan Endapan dari Air Gambut ( selama 2 minggu) dapat dilihat pada Tabel 2.

Dari Tabel 2 terlihat bahwa hasil analisis $\mathrm{pH}$ tanah pada setiap perlakuan setelah inkubasi Endapan dari Air Gambut (EAG) tidak terjadi perbedaan secara kriteria yaitu berada dalam kriteria masam. Namun bila dilihat dari angka - angka masih terjadi sedikit peningkatan.

Pada Tabel 2 diatas juga terlihat bahwa semakin tinggi takaran endapan air gambut maka kandungan Al-dd semakin kecil. Penurunan kandungan Al akibat pemberian EAG sebesar 0,8 ton (4g/polybag), 1,6 ton/ha ( $8 \mathrm{~g} /$ polybag), 2,4 ton/ha (12 g /polybag) dan 3,2 ton/ha (16 $\mathrm{g} /$ polybag) masing - masing terjadi penurunan sebesar 0,$02 ; 0,1 ; 0,16$; dan 0 , $33 \mathrm{me} / 100 \mathrm{~g}$ bila dibandingkan tanpa perlakuan.

Tabel 1. Hasil analisis beberapa sifat kimia Endapan dari Air Gambut.

\begin{tabular}{cc}
\hline Sifat kimia Endapan dari Air Gambut & Nilai \\
\hline $\mathrm{pH}$ & 3,43 \\
C-Organik (\%) & 56,70 \\
KTK (me/100g) & 97,60 \\
\% asam humat & 9,20 \\
$\%$ asam fulfat & 4,00 \\
\hline
\end{tabular}


Tabel 2. Hasil analisis beberapa sifat kimia Ultisol setelah diinkubasi dengan Endapan dari Air Gambut selama 2 minggu

\begin{tabular}{ccccc}
\hline Takaran & \multicolumn{4}{c}{ Sifat kimia } \\
\cline { 2 - 5 } $\begin{array}{c}\text { Endapan dari } \\
\text { Air Gambut } \\
\text { (ton/ha) }\end{array}$ & $\mathrm{pH} \mathrm{H}_{2} \mathrm{O}$ & $\begin{array}{c}\text { Al-dd } \\
(\mathrm{me} / 100 \mathrm{~g})\end{array}$ & $\begin{array}{c}\mathrm{KTK} \\
(\mathrm{me} / 100 \mathrm{~g})\end{array}$ & $\begin{array}{c}\text { P tersedia } \\
(\mathrm{ppm})\end{array}$ \\
\hline 0 & $4.63^{\mathrm{m}}$ & 1.78 & $14.66^{\mathrm{r}}$ & $20.58^{\mathrm{s}}$ \\
0.8 & $4.67^{\mathrm{m}}$ & 1.76 & $14.94^{\mathrm{r}}$ & $21.52^{\mathrm{s}}$ \\
1.6 & $4.69^{\mathrm{m}}$ & 1.68 & $15.60^{\mathrm{r}}$ & $21.75^{\mathrm{s}}$ \\
2.4 & $4.70^{\mathrm{m}}$ & 1.62 & $17.80^{\mathrm{s}}$ & $28.72^{\mathrm{s}}$ \\
3.2 & $4.72^{\mathrm{m}}$ & 1.45 & $17.10^{\mathrm{s}}$ & $29.10^{\mathrm{s}}$ \\
\hline
\end{tabular}

Keterang : $\mathrm{m}=$ masam $\mathrm{r}=$ rendah $\mathrm{s}=$ sedang

Nilai $\mathrm{pH}$ tanah ada kecendrungan meningkat, namun peningkatannya relatif kecil. Hal ini karena terjadi penurunan kandungan Al-dd tanah dimana Endapan dari Air Gambut menghasilkan asam - asam organik yang dapat mengikat Al membentuk komplek organo-Al sehingga hidrolisis $\mathrm{Al}$ relatif kecil dan sumbangan ion $\mathrm{H}^{+}$juga kecil. Menurut Tan (1998) menyatakan bahwa Al yang terjerap oleh komplek liat dapat terhidrolisis dan menghasilkan ion $\mathrm{H}^{+}$ sehingga kosentrasi ion tersebut meningkat dalam tanah. Dengan terjadi komplek antara Al dengan asam organik maka reaksi hidrolisis $\mathrm{Al}$ dapat dihalangi.

Pada Tabel dapat terlihat bahwa pemberian Endapan dari Air Gambut yang semakin tinggi maka KTK tanah semakin besar. Peningkatan nilai KTK dengan pemberian EAG sebesar 0,8 ton/ ha (4g/polybag), 1,6 ton/ha (8 g/polybag), 2,4 ton/ha (12 g/polybag) dan 3,2 ton/ha ( 26 $\mathrm{g} /$ polybag) berturut-turut sebesar 0,$28 ; 0,94$; 3,14; dan 2,44 me/100 g. Berdasarkan tabel kriteria tanah, nilai KTK tanah tanpa perlakuan berada pada kriteria rendah. Bila takaran Endapan dari Air Gambut ditingkatkan menjadi 0,8 ton/ha (4 $\mathrm{g} /$ polybag) dan 1,6 ton/ha ( $8 \mathrm{~g} /$ polybag) nilai KTK tanah masih dalam kriteria yang sama. Namun bila takaran ditingkatkan menjadi 2,4 ton/ha (12 g/polybag) nilai KTK tanah mengalami perubahan menjadi kriteria sedang demikian juga untuk takaran 3,2 ton/ha (16 g/polybag).

Peningkatan nilai KTK tanah ini seiring dengan meningkatnya takaran Endapan dari Air Gambut. Hal ini karena asam - asam organik dalam Endapan dari Air Gambut mempunyai gugus karboksilat $(-\mathrm{COOH})$ dan fenolat (-OH) yang merupakan sumber muatan negatif. Sedangkan KTK Endapan dari Air Gambut yaitu 97,60 me/100 g (Tabel 1), ini menunjukkan bahwa muatan negatif yang dimiliki oleh Endapan dari Air Gambut relatif lebih banyak. Stevenson (1994 cit Herviyanti, 2007) menyatakan bahwa nilai KTK asam humat disebabkan karena asam humat mempunyai sumber muatan negatif yang berasal dari gugus fungsional hidroksil dan karboksil. Semakin besar kosentrasi gugus fungsional asam humat maka semakin besar pula muatan negatif yang dikandungnya. Dengan adanya peristiwa ionisasi maka akan terbentuk tapak - tapak pertukaran sehingga kation lebih banyak terjerap. Dimana Herviyanti (2007) juga mengemukakan bahwa dengan meningkatnya sumber muatan negatif maka KTK tanah menjadi meningkat.

Pada Tabel 2 dapat dilihat bahwa nilai $\mathrm{P}$ tersedia masih dalam kriteria yang sama yaitu sedang. Hal ini diduga $P$ 
potensial tanah yang relatif kecil dan lama inkubasi yang relatif pendek. Kecendrungan peningkatan nilai $\mathrm{P}$ tersedia dalam tanah terjadi seiring dengan adanya peningkatan pemberian Endapan dari Air Gambut, mulai dari 0 ton/ha, 0,8 ton/ha ( $4 \mathrm{~g} /$ polybag), 1,6 ton/ha (8 $\mathrm{g}$ /polybag), 2,4 ton/ha (12 $\mathrm{g} /$ polybag) dan 3,2 ton/ha (16 g/polybag). Hal ini erat hubungannya dengan peningkatan $\mathrm{pH}$ tanah serta penurunan Aldd tanah. Peningkatan $\mathrm{P}$ tersedia akibat pemberian Endapan dari Air Gambut terjadi karena pelepasan $\mathrm{P}$ dari komplek $\mathrm{Al}$ - $\mathrm{P}$ melalui proses pertukaran anion fosfat dengan asam organik sehingga mengurangi retensi P dalam tanah (Gambar 1). Bradley dan Sieling (1953 cit Hakim, 1982) menyatakan asam - asam organik seperti asam humat dan fulfat berperan penting dalam mengikat $\mathrm{Al}$ dan $\mathrm{Fe}$ sehingga $\mathrm{P}$ tersedia meningkat. Asam - asam tersebut akan membentuk anion - anion organik yang efektif dalam mengurangi pengikatan $\mathrm{P}$ oleh $\mathrm{Al}$ dan $\mathrm{Fe}$. Hal ini juga dikemukakan oleh Tan dan Ahmad (1986 cit Nanda, 2005) bahwa dengan adanya penambahan bahan organik ke dalam tanah akan terjadi komplek dan khelat dengan ion Al yang reasinya digambarkan pada Gambar 1 .

\section{Inkubasi dengan dolomit yang diberikan sebagai pupuk}

Hasil analisis beberapa sifat kimia ultisol setelah diinkubasi dengan Dolomit yang diberikan sebagai pupuk sebanyak 500 $\mathrm{kg} / \mathrm{ha}\left(\begin{array}{ll}10 & \mathrm{~g} / \text { polybag}) \\ \text { selama } 1 & \text { minggu }\end{array}\right.$ setelah diinkubasi dengan Endapan dari Air Gambut dapat dilihat pada Tabel 3.

Pada Tabel 3 terlihat bahwa pemberian dolomit sebesar $500 \mathrm{~kg} / \mathrm{ha}(2,5 \mathrm{~g} /$ polybag $)$ dapat meningkatkan nilai $\mathrm{pH}$ tanah walaupun masih dalam kriteria yang sama yaitu masam. Dimana pada tanpa perlakuan setelah diberi dolomit, $\mathrm{pH}$ tanah meningkat dari 4,63 menjadi 4,76 (meningkat sebesar 0,13 unit $\mathrm{pH}$ ). Demikian untuk takaran 0,8 ton/ha (4 g/polybag), 1,6 ton/ha (8 g/polybag), 2,4 ton/ha (12 g/polybag) dan 3,2 ton/ha (16 g/polybag) masing masingnya meningkat dari 4,67 menjadi 4,77 (meningkat sebesar 0,1 unit pH) ; 4,69 menjadi 4,78 (meningkat sebesar 0,09 unit $\mathrm{pH}$ ) ; 4,70 menjadi 4,79 (meningkat sebesar 0,09 unit $\mathrm{pH}$ ) dan 4,72 menjadi 5,04 (meningkat sebesar 0,32 unit $\mathrm{pH}$ ).

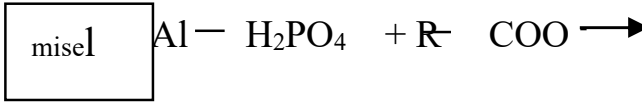

( $\mathrm{P}$ terikat )

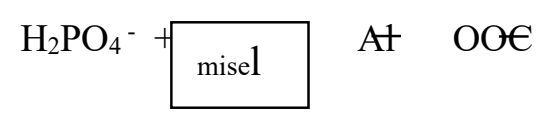

$\mathrm{R}$

(P-larut)

Gambar 1. Pelepasan P dari Al melalui proses pertukaran anion fosfat dengan asam organik sehingga mengurangi retensi $\mathrm{P}$ dalam tanah.

Tabel 3. Hasil beberapa sifat kimia ultisol setelah diinkubasi dengan Dolomit

\begin{tabular}{ccc}
\hline $\begin{array}{c}\text { Pada Perlakuan EAG } \\
\text { (ton/ha) }\end{array}$ & $\mathrm{pH} \mathrm{H}_{2} \mathrm{O}$ & $\begin{array}{c}\text { Al-dd } \\
(\mathrm{me} / 100 \mathrm{~g})\end{array}$ \\
\hline 0 & $4,76^{\mathrm{m}}$ & 1,70 \\
0,8 & $4,77^{\mathrm{m}}$ & 1,67 \\
1,6 & $4,78^{\mathrm{m}}$ & 1,66 \\
2,4 & $4,79^{\mathrm{m}}$ & 1,58 \\
3,2 & $5,04^{\mathrm{m}}$ & 1,43 \\
\hline
\end{tabular}


Pada masing - masingnya terjadi penururan kandungan Al-dd dari 1,76 menjadi 1,67 ; 1,68 menjadi 1,$66 ; 1,62$ menjadi 1,58 dan 1,45 menjadi $1,43 \mathrm{me} / 100 \mathrm{~g}$.

Penurunan kandungan Al-dd juga terjadi setelah diberi dolomit. Dimana pada tanpa perlakuan endapan dari air gambut setelah diberi dolomit, Al-dd menurun yaitu dari $1,78 \mathrm{me} / 100 \mathrm{~g}$ (Tabel 2) menjadi 1,70 me/100g (Tabel 3) atau sebesar 0,08 $\mathrm{me} / 100 \mathrm{~g}$. Demikian untuk takaran 0,8 ton/ha (4 g/polybag), 1,6 ton/ha (8 $\mathrm{g} /$ polybag) dan 3,2 ton/ha (16 g/polybag).

Penurunan kandungan Al-dd diduga karena dolomit mengandung ion $\mathrm{CO}_{3}{ }^{-2}$ yang akan menghasilkan ion $\mathrm{OH}^{-}$yang dapat menarik Al dari komplek jerapan sehingga dapat mengurangi reaksi hidrolisis $\mathrm{Al}$ yang nantinya juga mengurangi sumbangan ion $\mathrm{H}^{+}$dalam tanah sehingga $\mathrm{pH}$ tanah meningkat. Hal ini sesuai dengan pendapat Nyakpa et al (1988) bahwa ion karbonat $\left(\mathrm{CO}_{3}{ }^{-2}\right)$ dari kapur akan menghasilkan $\mathrm{OH}^{-}$ yang dapat menarik $\mathrm{Al}$ dari komplek jerapan sehingga terbentuk $\mathrm{Al}(\mathrm{OH})_{3}$ yang tidak aktif dan ion $\mathrm{Ca}^{+2}$ dan $\mathrm{Mg}^{+2}$ akan menggantikan $\mathrm{Al}$ dikomplek jerapan.

\section{Tinggi tanaman}

Tinggi tanaman jagung semi yang diberi Enadapan dari Air Gambut pada berbagai takaran disajikan pada Tabel 4 . Pada Tabel 4. terlihat bahwa pengaruh pemberian Endapan dari Air Gambut terhadap tinggi tanaman dapat meningkat secara nyata. Semakain tinggi takaran EAG maka tinggi tanaman semakin tinggi. Pada takaran 0,8 ton/ha (4 g/polybag) $\mathrm{EAG}$ terlihat tinggi tanaman jagung semi 156,70 $\mathrm{cm}$. Bila dibandingkan tanpa perlakuan $(0$ ton/ha) terjadi peningkatan sebesar 30,33 $\mathrm{cm}$. Demikian juga untuk 1,6 ton/ha (8g/polybag), 2,4 ton/ha (12 g/polybag) dan 3,2 ton/ha (16 g/polybag) EAG terjadi peningkatan masing - masingnya $42,83 \mathrm{~cm}$; $54,60 \mathrm{~cm}$ dan $72,10 \mathrm{~cm}$.

Penambahan pertumbuhan secara visual dapat dilihat pada Gambar 2. Dimana tanpa takaran Endapan dari Air Gambut jumlah daunnya lebih sedikit, batangnya agak kurus dibandingkan takaran 0,8 ton/ha (4 g/polybag), 1,6 ton/ha (8 g/polybag), 2,4 ton/ha (12 g/polybag) dan 3,2 ton/ha (16 g/polybag). Peningkatan tinggi tanaman ini dikarenakan pemberian Endapan dari Air Gambut dapat menurunkan kandungan $\mathrm{Al}$ (dari Tabel 2 menjadi Tabel 3), pH tanah meningkat (dari Tabel 2 menjadi Tabel 3) sehingga tingkat keracunan $\mathrm{Al}$ berkurang serta kadar $\mathrm{P}$ yang meningkat (Tabel 2). Selain itu diduga adanya penambahan $\mathrm{N}$ yang berasal dari tepung biji kelor yang mengandung protein yang merupakan sumber utama

Tabel 4. Tinggi tanaman jagung semi $(\mathrm{cm})$ yang diberi perlakuan Endapan dari Air Gambut (EAG) pada berbagai takaran.

\begin{tabular}{cc}
\hline $\begin{array}{c}\text { Takaran Endapan dari Air Gambut } \\
\text { (ton/ha) }\end{array}$ & $\begin{array}{c}\text { Tinggi tanaman } \\
(\mathrm{cm})\end{array}$ \\
\hline 0 & $126,37 \mathrm{a}$ \\
0,8 & $156,70 \mathrm{~b}$ \\
1,6 & $169,20 \mathrm{c}$ \\
2,4 & $180,97 \mathrm{~d}$ \\
3,2 & $198,47 \mathrm{e}$ \\
\hline
\end{tabular}

$\mathrm{Kk}=16,42 \%$

Angka-angka pada kolom yang sama yang diikuti huruf kecil yang sama berbeda tidak nyata menurut DNMRT 5\% 


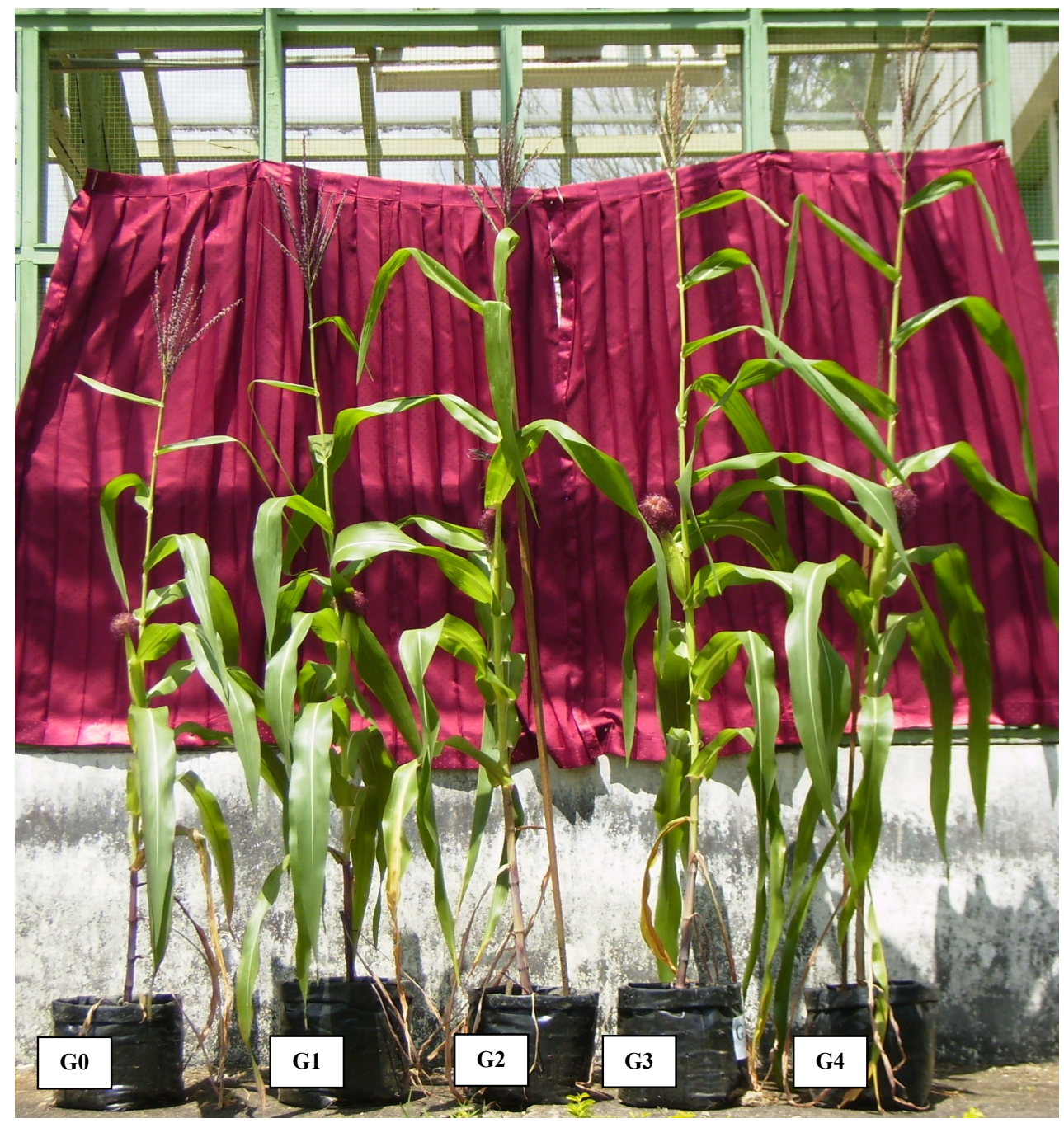

Keterangan : G0 = Tanpa Endapan Air Gambut, G1= 4 g Endapan dari Air Gambut/polybag (800 kg/ha), G2 $=8 \mathrm{~g}$ Endapan dari Air Gambut/polybag (1600 kg/ha), G3 = $12 \mathrm{~g}$ Endapan dari Air Gambut/polybag (2400 kg/ha), G4 = $16 \mathrm{~g}$ Endapan dari Air Gambut/polybag (3200 kg/ha).

Gambar 2. Tinggi tanaman jagung semi pada minggu ke

unsur N. Perbaikan beberapa sifat kimia tanah ini akan memperbaiki perakaran tanaman, sehingga serapan hara meningkat. Akibat peningkatan hara maka pertumbuhan tanaman menjadi lebih baik.

\section{Kadar Hara P tanaman}

Hasil analisis kadar hara $\mathrm{P}$ tanaman jagung semi menunjukkan bahwa pemberian Endapan dari Air Gambut memperlihatkan hasil yang berbeda nyata. Hasil rata - rata kadar hara $P$ tanaman jagung semi selengkapnya dapat dilihat pada Tabel 5 . Tabe15. Pengaruh pemberian Endapan dari Air Gambut terhadap P tanaman jagung semi $(\%)$ 


\begin{tabular}{cc}
\hline Gambut (ton/ha) & $(\%)$ \\
\hline 0 & $\left.0,13 \quad \mathrm{a}^{*}\right)$ \\
0,8 & $0,14 \mathrm{ab}$ \\
1,6 & $0,15 \mathrm{bc}$ \\
2,4 & $0,16 \mathrm{~cd}$ \\
3,2 & $0,17 \mathrm{~d}$ \\
\hline
\end{tabular}

$\mathrm{KK}=4,64 \%$

${ }^{*}$ Huruf kecil yang sama pada kolom yang sama berbeda nyata menurut DNMRT 5\%

Pada Tabel 5. terlihat bahwa peningkatan takaran Endapan dari Air Gambut semakin meningkatkan kandungan $\mathrm{P}$ tanaman. Meningkatnya kandungan $\mathrm{P}$ tanaman jagung semi akibat pemberian Endapan dari Air Gambut berhubungan dengan P-tersedia tanah (Tabel 2). Dimana pada Tabel 2 terlihat terjadi peningkatan $\mathrm{P}$ tersedia dengan adanya peningkatan pemberian Endapan dari Air Gambut. Peningkatan ini terjadi karena adanya reaksi dari asam asam organik yang berasal dari Endapan dari Air Gambut yang membentuk senyawa komplek dan khelat dengan Al sehingga mengurangi fiksasi $\mathrm{P}$ dalam tanah. Hal ini menyebabkan jumlah $\mathrm{P}$ yang tersedia di dalam tanah lebih tersedia dan dapat diserap oleh tanaman. Hal ini sesuai dengan pendapat Tan (1998) bahwa asam humat dengan gugus karboksil (-COOH) dan fenolik $(\mathrm{OH})$ dapat mengikat $\mathrm{Al}$ dan $\mathrm{Fe}$ membentuk komplek organo metal sehingga unsur P terbebas di dalam tanah dan dapat tersedia bagi tanaman.

\section{Berat basah tanaman dan berat tongkol tanaman jagung semi}

Berdasarkan hasil analisis sidik ragam dapat diketahui bahwa pemberian Endapan dari Air Gambut memberikan pengaruh yang nyata terhadap berat basah tanaman dan berat basah tongkol tanaman jagung semi. Hasil rata - rata berat basah tanaman dan berat basah tongkol tanaman jagung semi selengkapnya ditampilkan pada Tabel 6 .

Tabel 6. Pengaruh pemberian Endapan dari Air Gambut terhadap berat basah tanaman jagung semi dan berat tongkol jagung semi

\begin{tabular}{ccc}
\hline $\begin{array}{c}\text { Takaran Endapan dari Air } \\
\text { Gambut (ton/ha) }\end{array}$ & $\begin{array}{c}\text { Berat basah tanaman jagung } \\
\text { semi } \\
(\mathrm{g})\end{array}$ & $\begin{array}{c}\text { Berat tongkol tanaman } \\
\text { jagung semi }(\mathrm{g})\end{array}$ \\
\hline 0 & $206,88 \mathrm{a}$ & $38,99 \mathrm{a}$ \\
0,8 & $208,37 \mathrm{a}$ & $41,21 \mathrm{~b}$ \\
1,6 & $226,49 \mathrm{bc}$ & $44,93 \mathrm{c}$ \\
2,4 & $227,35 \mathrm{c}$ & $47,98 \mathrm{~d}$ \\
3,2 & $248,73 \mathrm{~d}$ & $49,35 \mathrm{~d}$ \\
\hline
\end{tabular}

$\overline{\text { Huruf kecil yang sama pada kolom yang sama berbeda tidak nyata menurut DNMRT 5\% }}$ 


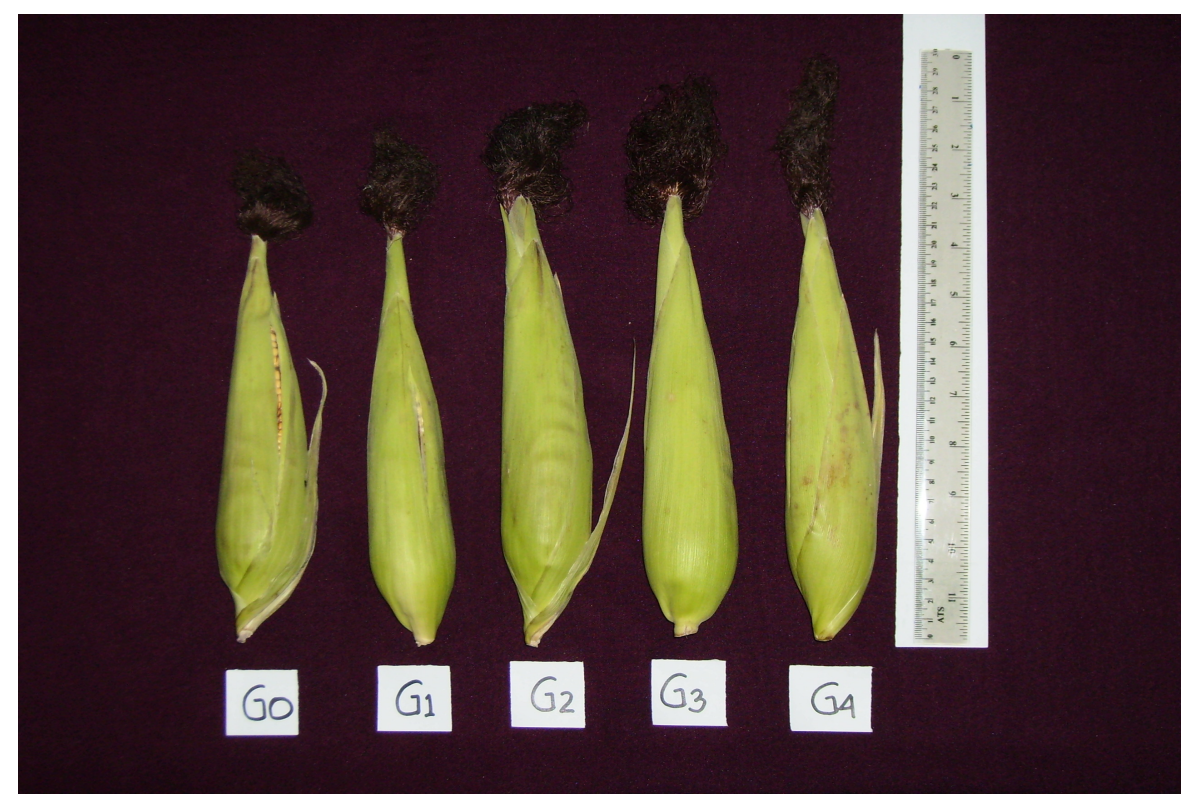

Keterangan : G0 = Tanpa Endapan Air Gambut (EAG), G1= 4 g EAG $/$ polybag $(800 \mathrm{~kg} / \mathrm{ha}), \mathrm{G} 2$ $=8 \mathrm{~g} \mathrm{EAG} /$ polybag $(1600 \mathrm{~kg} / \mathrm{ha}), \mathrm{G} 3=12 \mathrm{~g} \mathrm{EAG} /$ polybag $(2400 \mathrm{~kg} / \mathrm{ha}), \mathrm{G} 4=$ $16 \mathrm{~g} \mathrm{EAG} /$ polybag $(3200 \mathrm{~kg} / \mathrm{ha})$

Gambar 3. Tongkol tanaman jagung semi

Dari Tabel 6 terlihat bahwa peningkatan takaran Endapan dari Air Gambut semakin meningkatkan berat basah tanaman dan berat tongkol jagung. Peningkatan berat basah tanaman jagung semi dengan pemberian 0,8 ton/ha ( 4 $\mathrm{g} /$ polybag), 1,6 ton/ha (8 g/polybag), 2,4 ton/ha ( $12 \mathrm{~g} /$ polybag) dan 3,2 ton/ha (16 g/polybag)berturut-turut adalah 1,49 g 19,61 $\mathrm{g} ; 20,47 \mathrm{~g}$ dan $41,85 \mathrm{~g}$ sedangkan untuk berat tongkolnya berturut-turut adalah 2,22; 5,94; 8,99; dan 10,36 g . Hasil tanaman jagung semi dapat dilihat pada Gambar 3 .

Peningkatan berat basah tanaman dan tongkol tanaman jagung semi ini akibat pemberian Endapan dari Air Gambut yang dapat menurunkan kandungan $\mathrm{Al}$ yang tinggi, $\mathrm{P}$ tersedia di dalam tanah meningkat (Tabel 2) sehingga kesuburan tanah pun meningkat. Ini nantinya menyebabkan perakaran tanaman berkembang dengan baik dan penyerapan unsur harapun membaik sehingga pertumbuhan tanaman jagung semi meningkat. Dimana Al membentuk senyawa komplek dan khelat dengan asam-asam organik, sehingga pengikatan $\mathrm{P}$ oleh $\mathrm{Al}$ berkurang dan $\mathrm{P}$ lebih tersedia dan dapat diserap oleh tanaman dan ini mengakibatkan berat tanaman meningkat (Nyakpa et al, 1988).

Pospor (P) merupakan unsur utama yang dibutuhkan tanaman jagung disamping $\mathrm{N}$ dan $\mathrm{K}$. Peranan $\mathrm{P}$ secara umum amat penting dalam menyimpan dan mentranfer energi, penyusun protein, perbaikan kualitas tanaman dan untuk ketahanan tanaman (Hardjowigeno, 2003), disamping itu P dapat mempercepat pembungaan, pemasakan buah dan biji serta gabah dan meningkatkan produksi biji-bijian (Sutedjo, 1994).

\section{KESIMPULAN}

Berdasarkan hasil penelitian tentang Penggunaan Endapan dari Air Gambut Terhadap Beberapa Sifat Kimia Ultisol dan Hasil Tanaman Jagung Semi (Zea mays L) yang telah dikemukakan, dapat ditarik beberapa kesimpulan sebagai berikut :

1. Pemberian Endapan dari Air Gambut pada Ultisol dapat memperbaiki beberapa sifat kimia Ultisol diantaranya 
dapat menurunkan kandungan Al-dd tanah dari 1,79 menjadi 1,45 (takran 3,2 ton/ha endapan air gambut), menaikan $\mathrm{pH}$ tanah dari 4,52 menjadi 4,72 unit $\mathrm{pH}$ (takaran 3,2 ton/ha endapan air gambut), KTK dari 14,45 menjadi $17,10 \mathrm{me} / 100 \mathrm{~g}$ (takaran 3,2 ton/ha endapan dari air gambut) dan ketersedian P dari 19,79 menjadi 29,10 ppm (takaran 3,2 ton/ha endapan dari air gambut) dalam tanah.

2. Takaran Endapan dari Air Gambut yang optimal dalam mendukung hasil tanaman jagung semi belum didapatkan dan masih cendrung meningkat, namun pada takaran 3,2 ton/ha (16 g/polybag) yaitu $49,35 \mathrm{~g} /$ polybag $(2,4 \mathrm{ton} / \mathrm{ha})$ merupakan hasil yang tertinggi bila dibandingkan dengan tanpa perlakuan (0 ton/ha), 0,8 ton/ha (4 g/polybag), 1,6 ton/ha ( $8 \mathrm{~g} /$ polybag) dan 2,4 ton/ha (12 $\mathrm{g} /$ polybag).

\section{DAFTAR PUSTAKA}

Hakim, N. 1982. Pengaruh Pemberian Pupuk Hijau dan Kapur Pada Tanah Podzolik Merah Kuning Terhadap Ketersidiaan Pospor Pada Produksi Jagung (Zea may L). [Disertasi]. Bogor. Doktor Fakultas Pascasarjana Institut Pertanian Bogor. 271 hal.

Hakim. N., M. Y. Nyakpa., M. M. Lubis., M. A. Pulung., M. R. Saul., M. A. Diha., G. B. Hong., H. H. Bailey. 1984. Penuntun Praktikum Dasar-dasar Ilmu Tanah. Padang. Fakultas Pertanian Universitas Andalas. 141 hal.

1986. Dasar-

dasar Ilmu Tanah. Bandar Lampung . Fakultas Pertaian Universitas Lampung. 488 hal.

Hardjowigeno, S. 2003. Ilmu Tanah. Jakarta. AkademiPressindo. 286 hal.
Herviyanti. 2007. Upaya Pengendalian Keracunan Besi $(\mathrm{Fe})$ Dengan Asam Humat Dan Pengelolaan Air Untuk Meningkatkan Produktifikatas Ultisol Yang Baru Disawahkan. [Disertasi]. Padang. Doktor Program Pasca Sarjana Universitas Andalas. 177 hal

Iskandar, D.2005. Sanggaran Kos dan Pulangan Tanaman Bagi Sehektar5 Semusim Tanaman Jagung Manis (Zea mays saccaharata) Proseding seminar teknologi untuk negeri vol II. 1-5 halaman.

Kusnaedi. 1995. Mengolah Air Gambut dan Air Kotor untuk Air Minum. Cetakan ke-1. Jakarta. Penebar Swadaya. Hal 12-23

Nanda, L. 2005. Perbandingan Ketersediaan Fosfor (P) Dengan Pemberian Kapur, Pupuk Kandang dan Silikat Serta Pengaruhnya Terhadpa Serapan P dan Produksi Tanaman Jagung (Zea mays L) Pada Oxisol. [Skripsi]. Padang Universitas Andalas Padang. 63 hal.

Nyakpa, M. Y., A. M. Lubis, M. A. Pulung, A. G. Amrah, A. Munawar, G. B. Hong dan N.Hakim, 1988. Kesuburan Tanah. Lampung. Universitas Lampung. 258 hal.

Rahma, D. S. 1998. Efektifitas Protein Hasil Isolasi Dari Biji Kelor Terhadap Penjernihan Air Rawa Gambut. [Skripsi]. Padang. Fakultas Matematika dan Ilmu Pengetahuan Alam Universitas Andalas. 38 hal.

Sarief, S. 1986. Kesuburan dan Pemupukan Tanah Pertanian. Bandung. Pustaka Buana. 182 hal.

Soeprapto, H. S. 1991. Bertanam Jagung. Jakarta. Penebar swadaya. 59 hal. 
Sutedjo, M.M. 1994. Pupuk dan Cara Pemupukan. Jakarta. Rineka Cipta. 177 hal.

Syam, R. P. S. 2006. Pengaruh Pemberian Asam Humat Terhadap Ketersediaan Dan Serapan Hara P Tanaman Jagung (Zea mays L) Pada Ultisol. [Skripsi]. Padang. Fakultas Pertanian Universitas Andalas . 71 hal.
Tan, K.H. 1998. Dasar- dasar Kimia Tanah penerjeman; D. Goenadi. Penyunting. Yogyakarta. Gadjah Mada University Press.Terjemahan dari : Principles of Soil Chemistry. 295 hal.

Taufik, L dan Nursanah. 1985. Pengolahan Air Rawa Gambut. Puslitbang PU. Edisi 85. Dinas Pengairan Padang. Padang. hal $26-30$ 